\title{
Viticulture Suitability in Western Slopes of Jabal Al-ArabAn Integration of Bioclimatic, Soil, and Topographic Indicators for Viticulture Suitability Using Multi-Criteria Evaluation: A Case Study in the Western Slopes of Jabal Al-Arab - Syria
}

\author{
Karam Alsafadi, S. Mohammed, H. Habib, S. Kiwan, S. Hennawi \& M. Sharaf
}

To cite this article: Karam Alsafadi, S. Mohammed, H. Habib, S. Kiwan, S. Hennawi \& M. Sharaf (2019): Viticulture Suitability in Western Slopes of Jabal Al-ArabAn Integration of Bioclimatic, Soil, and Topographic Indicators for Viticulture Suitability Using Multi-Criteria Evaluation: A Case Study in the Western Slopes of Jabal Al-Arab - Syria, Geocarto International, DOI: 10.1080/10106049.2019.1583291

To link to this article: https://doi.org/10.1080/10106049.2019.1583291

Accepted author version posted online: 01 Mar 2019.

Submit your article to this journal $₫$

View Crossmark data $₫$ 


\section{An Integration of Bioclimatic, Soil, and Topographic Indicators for}

Viticulture Suitability Using Multi-Criteria Evaluation: A Case Study in the Western Slopes of Jabal Al-Arab - Syria

Karam Alsafadi*, S. Mohammed, H. Habib, S. Kiwan, S. Hennawi, M. Sharaf

*Corresponding author

Karam Alsafadi

PhD. Student

Alexandria University

Department of Geography and GIS

Alexandria, Egypt, 25435.

karam.alsafadi@alexu.edu.eg https://orcid.org/0000-0001-89257918

Tel: +20 1063705470

+201553992055

\section{S. Kiwan}

$\mathrm{PhD}$. in soil science

GCSAR

Damascus, Syria,30612

Samer_k@gmail.com

\section{S. Mohammed}

University of Debrecen

PhD. Student

Institute of Land Use

Debrecen, Hungary, 4032

safwan@agr.unideb.hu

https://orcid.org/0000-0003-2311

$\underline{6789}$

\section{S. Hennawi}

$\mathrm{PhD}$. in soil science

GCSAR

Damascus, Syria,30612

Hennawi s@gmail.com

\section{H. Habib}

Professor of soil science

Damascus University

Department of soil science

Damascus, Syria,30612

hhabib@scs-net.org

\section{Sharaf}

Professor of climatology

Alexandria University

Department of Geography and GIS

Alexandria, Egypt, 25435

Sharaf20s@hotmai.com

Running Title: Viticulture Suitability in Western Slopes of Jabal Al-Arab

Word Count: 7869 (with references) 


\title{
An Integration of Bioclimatic, Soil, and Topographic Indicators for Viticulture Suitability Using Multi-Criteria Evaluation: A Case Study in the Western Slopes of Jabal Al-Arab - Syria
}

\begin{abstract}
:
In the 21st century, Geographic Information Systems (GIS) have become one of the leading technologies in different sectors for development and planning, particularly in modern agricultural management. Moreover, recent advances in GIS tools and methods have helped decision-makers as well as farmers to find optimal sites for production of different crops. The cultivation of vineyards and grapes is one of the most important agricultural activities in the Al-Sweidaa governorate-Syria, which has been suffering from a decrease in annual productivity in conjunction with an increase in the annual demand for grapes and wine products, particularly in recent decades. Therefore, the aim of this research was to establish a new method for analysing the optimum regions for economic viticulture production in the Western Slopes of Jabal Al Arab in the AlSweidaa governorate by using Multi Criteria Evaluation (MCE). To this end, a field survey was conducted and a soil sample was collected for physical and chemically analysis, and a 1984-2014 MRm.30-meter resolution dataset of climatic variables for the Al-Sweidaa governorate was set up as well. The results show that suitable areas are concentrated in the higher part of the study area (the eastern part) where climate and soil are favourable, and did not show any relevant limitations. Conversely, the lower part of the study area (the western) has unfavourable climate and soil chemical and physical fertility; therefore grape production is only possible if irrigation is applied and the fertility properties of the soil are improved, particularly the percentage of organic matter and the soil texture.
\end{abstract}

Keywords: Multi Criteria Evaluation, Multivariate Regression Models, ClimateViticulture Indices, Jabal Al Arab and Analytical Hierarchy Process.

\section{Introduction}

Suitability is a key function for assessing crop requirements, as well as the characteristics of land for a particular use; it measures the conformity of land unit characteristics to the requirements of a form of use (FAO 1976), and the capacity of a given type of land to support specific use (Duc 2006). Moreover, many systems-research methods and several tools relating to information technology have become available for modern agriculture, such as GIS and RS technologies and have become widely used in the management of multiple crops in several scales (Acharya and Yang 2015). In addition, Multi Criteria Evaluation (MCE) has been developed to enhance spatial decision-making when evaluating a range of alternatives based on conflicting and unequal criteria, such as the evaluation of several crops in a land unit to support sustainable development (Mustafa et al. 2011). Therefore, farmers can now 
select the best or most suitable site for the cultivation of their crops or modify a pattern of land use according to crop requirements and based on environmental criteria such as climate, soils and topography properties. Vineyards are one of the most common cultivations around the world, and due to their value in the production of grapes and wine, the suitability of vineyards has been one of the most frequently studied of all crops in many regions (Watkins et al. 1997; Jones 2005; Jones et al. 2009; Anderson et al. 2012; Köse 2014; Fraga et al. 2014; Acharya and Yang 2015; MacCracken and Houser 2016; Mills-Novoa et al.2016; Hunter and Bonnardot 2011; Stanchi et al. 2013). Some of this research has focused on analysis of climate-viticulture as an input processing of the evaluation of suitability, and some on environmental suitability in general (soils, topographic elements, land cover, climate and geology). Overall, local and regional climate is essential for determining vineyard site suitability (Winkler et al. 1974). Understanding climate variables, including temperature, humidity, precipitation, sunshine and wind, is important for determining suitability. Each of these variables has a different degree of influence on wine grape growth (MacCracken \& Houser 2016). However, past studies have shown that temperature plays a dominant role. (Winkler et al. 1974; Jacob 1950; Barans et al. 1946; Amerine and Winkler, 1944; Tonietto and Carbonneau, 2004). As an example, cooler climates, with a mean pre-harvest temperature below $15^{\circ} \mathrm{C}$ have a significant impact on - and are a clear challenge for - wine grape growth and its maturity on appropriate dates; this climate condition produces grapes and wines with lower sugar, higher acid, high pH, and lower yields per land unit (Jackson 2000). Hotter climates with a mean temperature high than $35^{\circ} \mathrm{C}$ during grape growth also have a negative impact (Blanco-ward, et al. 2017). Due to the importance of temperature, a wide range of climate-viticulture indices have been proposed which use the temperature element as the most relevant variable for growing grapes and one essential for determining vineyard site suitability (Winkler et al. 1974; Huglin 1978; Gladstones 1992; Barans et al. 1946; Tonietto and Carbonneau 2004). Some of the indices which have been proposed use interaction between the number of actual sunlight hours, accumulated temperature, and the amount of precipitation in the growing season (Barans et al. 1974; Barans et al. 1946). These indices have been applied to define vinicultural regions on both a global and a local scale (Anderson et al. 2012; Mills-Novoa et al. 2016; Fraga et al. 2014; Jones et al. 2010; MacCracken and Houser, 2016; Köse 2014; Lorenzo et al. 2013; Mesterházy et al. 2013; Hunter and Bonnardot 2011; Blanco-ward, et al. 2017). This was the case with Jabal Al Arab in Syria, and was based on 1984-2014 MRm.30-meter resolution grids dataset of climatic variables for the Al-Sweidaa governorate (Alsafadi 2016), and showed elements such as the average of 
minimum and maximum temperature, precipitation, the number of actual sunlight hours, and the extreme temperature events through the vineyards' growing season.

In addition to the above, vineyards are often characterized by limited amounts of wines and grapes with steep slopes, low soil fertility, and dryness (Stanchi et al. 2013; Alganci el al. 2018). So climate and soil characteristics play an important role compared to other variables in the interaction with vineyards to produce wines and grapes in higher quality (Kumara and Sendanayake 2016; Kurtural et al. 2006; Ubalde et all. 2010).

Overall, the main aim of this research is to integrate the analysis of climate-viticulture indices with soil and topography criteria and consider them in terms of vineyard suitability. To our knowledge, this is the first study in which climate, soil, and topography have been jointly studied to analyse the viticultural western slopes of Jabal Al Arab.

\section{Study Area}

The study area is located in the western part of the Al-Sweidaa Governorate, in southern Syria, between $32^{\circ} 28^{\prime} 15^{\prime \prime} \mathrm{N}, 36^{\circ} 24^{\prime} 18^{\prime \prime E}$ and $32^{\circ} 46^{\prime} 44^{\prime \prime N}, 36^{\circ} 45^{\prime} 15^{\prime \prime E}$ ) (Fig. 1a). This region has a Mediterranean wet climate (Csb) in higher areas with dry summers and temperate winters, while in the lower areas it has a cold semi-arid climate (Bsk) according to the Kopin classification; mean annual precipitation is between 250 and $550 \mathrm{~mm}$, more than $80 \%$ of which falls from October to April (Alsafadi 2016). It covers an area of $523 \mathrm{~km}^{2}(52300$ hectares). Altitude ranges between $696 \mathrm{~m}$ in the west and $1795 \mathrm{~m}$ in the east (Tall Qeni). The agricultural area is around $83.66 \%$ of the study area (Fig. 1b). The total viticultural area was around 10125 ha in 2015, although it was 15497 hectares in 1991, according to SMOAAR (2015). This area decreases annually, due to the frequency of cold and heat waves, and high production costs.

Fig. 1(a) Location of the study area from the Al-Sweidaa governorate and sites of soil profiles, (b) Land cover map.

\section{Data and Methods}

\subsection{Climatic, Topographic and Soil Data}

In order to accurately calculate and analyse temperature-based climate indices for this research, we used 1984-2014 MRm.30-meter (Multivariate Regression Models), high resolution grid datasets of climatic variables for the Al-Sweidaa governorate (Alsafadi 2016), 
which include details such as average minimum and maximum temperature (from April to October), seasonal precipitation, the number of actual sunlight hours and extreme temperature events through the vineyards' growing season. The grids were based on daily data collected from climate stations in the Al-Sweidaa governorate and other climate stations outside the study area such as Daraa, Alqunaytra, Damascus, and North of Jordan, for the period 1984-2014. Individual weather stations in the study area can only record information at their specific sites, but the grid data cover the entire study area and take into consideration the gradient of climate elements over a short distance caused by the complexity of the topography. The grids data were created with an analysis of the Multivariate Regression Model, using latitude, longitude, distance from coastal line, elevation, slops, and aspect as requested variables, and climatic variables as dependent variables, which means reproducing the equation of the regression fit using the raster matrices of the independent variables. The outcome of this procedure is a raster matrix map for each month with high resolution $(30 \mathrm{~m}$ by $30 \mathrm{~m}$ ) regular grids. The annual and seasonal temperature and precipitation grids have been shown to have Std. Error estimated at between 0.3 and $0.7{ }^{\circ} \mathrm{C}$ for temperature layers and $37 \mathrm{~mm}$ for precipitation layers (Alsafadi 2016). These temperature grids, along with other climate parameter grids, have been used in developing climatic suitability maps for growing vine-grapes in the study area.

For the topographic analysis, elevation, geographical aspect and slopes were selected as the leading elements to be studied in suitability processing, due to their importance in viticulture. For this study, data were collected from available sources on the web. The main input data are from a DEM: a Digital Elevation Model of the study area (Fig. 3.a) which was clipped from NASA's Shuttle Radar Topography Mission (SRTM). These data grids have a $1^{\circ}$ arc-sec global (approx. 30m) resolution (https://earthexplorer.usgs.gov). The DEM was later used to generate slope (Fig. 3.b), hill-shade (Fig. 3.c), and aspect (Fig. 3.d) maps.

Analysed soil data was obtained from soil survey and laboratory analysis conducted in the study area (Kiwan 2014; Hennawi and Habib 2013; Hennawi and Habib 2012; Habib 2006). Following this, the values of the soil characteristics were recalculated using a weight factor, and then the new data were converted to grid datasets by the Kriging method as a geostatistical surface high resolution of 30 by $30 \mathrm{~m}$, and then classified for vineyard suitability. 
The map of present land cover distribution has been elaborated from Bing Images high resolution $8 \mathrm{~m}$ by $8 \mathrm{~m}$ (www.giscloud.com), after rectification and geo-referencing using ArcMap 10.5 (Fig.1b).

\subsection{Data Analysis}

\subsubsection{Climate-Viticulture Indices and Extreme Temperature Events}

The Climate-viticulture indices are presented in Table1. Five climatic indices were calculated to evaluate the climate of the western slopes of Jabal Al Arab in terms of sunshine duration, precipitation and heat summation requirements for viticulture. (1) Branes Heliothermic Index (BHI): developed by Branas et al. (1974), this index combines the number of actual sunshine hours and the temperature during the growing season. BHI is used to evaluate grape regions, cultivar adaptation, phenological development and ripening characteristics (Köse 2014). (2) The Hydrothermal Coefficient (HTC) which was developed by Branas et al. (1946) combines the effect of the amount of seasonal precipitation and temperature during the growing season; this is a characteristic number, which measures the water supply for vegetation, and determines the possibility of rainfed viticulture (Alsafadi 2016; Mesterházy et al. 2013). In regions where $\mathrm{HTC}$ values are below $0.5 \mathrm{~mm} /{ }^{\circ} \mathrm{C}$, grape production is only possible if the air humidity is high or if irrigation is applied. The maximum value of the HTC is 1.5-2.5 $\mathrm{mm} /{ }^{\circ} \mathrm{C}$, while the optimal value is $1.0 \mathrm{~mm} /{ }^{\circ} \mathrm{C}$ (Mesterházy et al. 2013). (3) The Winkler Index (WI-GDD): this makes use of the sum of the daily average temperatures between April and the end of October. WI-GDD provides information on the accumulation of heat during the growing season for vineyards with a base temperature of $10{ }^{\circ} \mathrm{C}$ (Amerine and Winkler 1944). (4) The Huglin Index (HI): this was developed by Huglin (1978). HI values are computed similarly to WI-GDD but its processing calculation includes a high weighting for maximum temperature and an adjustment based on latitude; i.e. the coefficient length of the day (Huglin 1978). In addition, it provides better information regarding the sugar potential of given varieties, and thus provides qualitative information combined with the values of the CI cool night index (Tonietto and Carbonneau, 2004). Jones et al. (2009), and Hall and Jones (2010) have updated the HI formula for all latitudes, using the months from April to September (in the Northern Hemisphere), leaving out October, as they suggested that harvesting during that time made the values less important (Jones et al. 2010; Anderson et al. 2012). (5) The Cool Night Index (CI): this was developed by Tonietto and Carbonneau (2004) and is a night coolness variable which takes into consideration the mean minimum 
night temperatures during the month when ripening usually occurs (i.e. September). This climatic factor is also important as regards grape and wine colour and aromas; CI is recommended for improving the assessment of the qualitative situation of wine-gapes, in relation to secondary metabolites in grapes juice, such as aromas and polyphenols. (Kliewer and Torres 1972; Kliewer 1973). The calculation for the determination of CI is as follows: in the Northern Hemisphere: $\mathrm{CI}=$ minimum air temperature in the months of September (mean of the minima), in ${ }^{\circ} \mathrm{C}$. In the Southern Hemisphere: $\mathrm{CI}=$ minimum air temperature in the months of March (mean of minima), in ${ }^{\circ} \mathrm{C}$ (Tonietto and Carbonneau, 2004). Thus, categorized climate-viticulture indices allow us to determine the optimum climatic suitability in terms of heat and water availability and phenological development during the growth season, as well as ripening conditions (Fraga et al. 2014).

Table 1 Climate-Viticulture Indices (bioclimatic), definitions and classified limits

Bearing in mind the discussion above regarding the complex climate influences on growing grapes and wine production, is there an ideal climate for vineyards? Jones (2015) suggested an optimum zone, where it is best to match the cultivars to the climate condition, as shown in Fig. 2. In the optimum zone a cultivated cultivar will produce higher quality grapes and wine as it provides an appropriate growth period and tends to balance the four ripeness clocks that are evolving simultaneously but at different averages - acid respiration, sugar accumulation, fruit character, and phenolic ripeness (Jones et al. 2005; Jones et al. 2010). Furthermore, any given grape cultivar has thresholds related to the climate; if it is being grown in very cool regions, this will lead to lower sugar levels, higher acid retention, unbalanced wines and unripe flavours. Conversely, if a given grape cultivar is being grown in a very warm region, this will lead to lower acid retention, higher sugar levels, unbalanced wines and overripe flavours (Jones 2015). According to the previous proposal, the current study has classified the values of HI and WI-GDD by dividing them into several limits as shown in Table 6. The very cold and the very warm limits were given little importance; on the other hand, the moderate zone was given great importance because it achieves a balanced growth.

\section{Fig. 2 Relationship and thresholds between climate and wine production and quality} metrics (Jones 2015)

In addition to the above five climate-viticulture indices, the heat waves and the cold waves (the number of days below $15^{\circ} \mathrm{C}$ during the flowering period (NDb15), and the number of 
days over $35^{\circ} \mathrm{C}$ during the ripening period (NDh35)) have been computed and estimated based on the daily minimum temperature of May for cold waves, and the daily maximum temperature of July and August for heat waves, using cubic equations and nonlinear regressions to estimate these climatic parameters for the study area, as shown in Table 2 . The frequency of heat waves during the ripening stage has a negative effect on vineyard vegetation and grapes, and on wine production, particularly when the temperature is above 35 ${ }^{\circ} \mathrm{C}$ (Mesterházy et al. 2013; Alsafadi 2016; Blanco-ward, et al. 2017). In addition, the frequency of cold waves during the flowering stage has a direct effect (Alsafadi, 2016); when the mean daily temperature was $15^{\circ} \mathrm{C}$ or below, no inflorescences were produced (Vasconcelos 2009).

Table 2 Estimation of the frequency of heat waves and cold waves during ripening and flowering stages, based on daily temperature data from 1984 - 2014 at Alswuydaa and

\section{Ain Al-Arab stations}

\subsubsection{Soil Sampling and Indicators}

To achieve the study goals a soil survey was conducted in the study area by dividing it into 10 zones according to climatic characteristics and geomorphological aspects. As a result, more than 56 soil profiles were dug till the bedrock was reached and were described according to the system outlined by the FAO (1990). Following this, 244 soil samples were transferred to the soil laboratory at the General Commission of Scientific Research, Damascus, Syria, to analyse the soil texture (Day 1965), the electrical conductivity (EC) of (1:5) the soil $\mathrm{dS} / \mathrm{m}$ (Rhoades 1983), the soil reaction $(\mathrm{pH})$ of (1:2.5) the soil (Melan 1982), the organic matter \% (Nelson and Sommers 1982), and the CaCO3\% (Nelson and Sommers 1982). Laboratory results were recalculated and modified for each characteristic and each profile by using a weighting factor (Sys et al. 1991) as shown (Table 3).

\section{Table 3 Weighting factor classification}

The six soil indicators were classified to evaluate a soil's suitability for vineyards on the western slopes of Jabal Al Arab, as follows: (1) Organic Matter (OM): organic matter contributes through structure, nutrients, moisture available in the soil, and porosity. The organic matter gives a pool of slowly available nitrogen to support vineyard growth. OM values greater than 5 percent are counter-productive because the excessive nitrogen released by OM decomposition may lead to excessive vegetative growth; the desired values for 
vineyard soils are 2-3 percent (Kurtura et al. 2008; Wolf and Boyer 2003). (2) Soil Texture: all soil texture classes show their properties in terms of agricultural use. Sandy soils have coarse particles and are usually excessively drained, with low water retention capacity. Conversely, clay soils have small particles and retain large amounts of water, but its discharge is poor and usually difficult to manage. With relatively even proportions between particles, loamy soils are typically well drained and provide sufficient nutrient retention and are thus usually preferable for agricultural use (Fraga et al. 2014; White 2009). Therefore, the relatively even proportion between particles has been calculated based on the total proportion of each sand and silt to clay, in order to evaluation the quantitative importance of these particles, especially the soil of the study area characterized by a high clay content, and to implement soil texture as a dataset layer. (3) Soil $\mathrm{pH}$ : soil $\mathrm{pH}$ gives an indication of nutrient balance and fertility; most studies have found that preferred values for vineyard growing are between 5.5 and 8.0; nutrients may become out of balance outside this range (Jones, 2004). Soil $\mathrm{pH}$ values from 6.0 to 6.8 provide the optimum availability of nutrients in vineyard soils (Kurtura et al. 2008; Wolf and Boyer 2003; White 2003). (4) Electrical Conductivity (EC): this is linked to or indicates the soil's salinity levels; vineyards are sensitive to high salinity levels, so vineyard damage and poor growth can occur as a result of an "osmotic effect" as roots strive to uptake salty water; the optimum value is $>2 \mathrm{dS} / \mathrm{m}$ (Labay 2017: Cass et al. 1995; Lanyon et al. 2004), although, vine rootstock can tolerate EC up to $4 \mathrm{dS} / \mathrm{m}$ (White 2003). (5) Soil Depth: a deep soil (> $100 \mathrm{~cm}$ ) offers a greater volume of potential soil moisture than does a shallow soil $(<40 \mathrm{~cm})$. Vineyards can be grown on shallow soils; however, these vines will suffer from drought if supplementary water is not available by irrigation (Wolf and Boyer 2003). (6) Calcium Carbonate (CaCO3): generally, $\mathrm{Ca}+$ plays a good role in the soil by improving soil structure and soil aggregation, but badly affects the mineralization rate of the soil organic matter (Virto et al. 2018), Lebrun (2016) mentioned that the soil $\mathrm{Ca}+$ content could affect the wine's properties.

\subsubsection{Topography}

The terrain of a site is recognized as having an influence on grape-vine production by affecting its mesoclimate (Gladstones 1992). Slopes are important for soil water drainage, and are necessary and critical in the growing of vineyards. Slopes steeper than $15 \%$ are not recommended because of the risk of the downhill drift of towed equipment in the vineyard rows (Wolf \& Boyer 2003). However, a geographical aspect refers to the predominant 
directional orientation of a slope, and this is important in terms of its effects on the total heat balance of a vineyard (Chen 2011). Aspect will affect the angle at which sunlight hits the vineyard and its total balance of heat. Vineyards should be exposed to direct sunlight for at least a part of the day; eastern aspects are probably optimal (Gladstones 1992). Therefore, aspect and slope data were calculated based on DEM data using surfaces analysis in ArcGIS software, as shown in (Fig. 3).

\section{Fig. 3 Topographic characteristics (a) elevation (b) slope-percentage}

\section{(C) hill-shade, (d) aspect}

\subsection{Multi-criteria Evaluation (MCE)}

Evaluation of multi-criteria is an integrated process which selects better alternatives where a decision has to be taken considering several constraints and factors depending on their relative importance to the final objective, integrated with GIS tools and procedures (Malczewski 1999; Malczewski 2000; Carver 1991). Several practical techniques are used for land suitability analysis, for example, Weighted Linear Combination (WLC) or Sum, depending on the nature of the input layers (Kumara \& Sendanayake 2016; Dengiz and Usul 2018). Many studies have set several criteria and factors for selecting the best sites for vineyards based on the soil and topography properties (Watkins et al. 1997; Jones et al. 2004; Ghosh 2005; Happ2014; Acharya and Yang 2015; Alganci el al. 2018), while others have focused on analysis of bioclimatic indices in suitability evaluation (Mills-Novoa et al. 2016; MacCracken and Houser 2016; Campbell 2013; Jones et al. 2010; Anderson et al. 2012; Koufos2017; Blanco-ward, et al. 2007; Santos et al. 2018). However, a few studies have integrated the analysis of climate-viticulture indices, with soil, topography and land cover criteria, for consideration of vineyard suitability (Kurtural et al. 2006; Stanchi et al. 2013; Fraga et al. 2014). This has been done in this research, which has applied vineyard suitability on two levels: the first level includes three main criteria (climate, soil, and topography) and the second includes many sub-criteria within the main criteria, as explained in Table. 6, and applied as shown in Fig.4.

Second level or sub-criterion ranks are computed for each layer. These values are combined with weight (calculated using the AHP method) to provide a suitability value for each layer. The formula is as follows:

$$
\mathrm{S}=\left[\sum_{\mathrm{i}=1}^{\mathrm{n}} \mathrm{Wi} * \mathrm{Xi}\right] \Pi c \mathrm{j}
$$




\section{S: $\quad$ Suitability index \\ wi Weight of criterion $\mathrm{i}$ \\ xi: Rank of criterion i \\ cj: Boolean value of limited criterion}

The above formula is applied to each layer. Overall, a higher final $\mathrm{S}$ value indicates a higher suitability for viticulture. In our experiment, cj takes a value of 1 or 0 . A value of 0 is applied to a land cover mapping unit which is not suitable due to its natural conditions, i.e. for water bodies, buildings and public facilities; 1 is for other types of land cover. Consequently, the Boolean value in our study is land cover pattern, by a value of 0 and 1 , where urban areas were excluded from final suitability using the algebra calculator in GIS tools, as shown in Fig.4.

The land suitability system is divided into suitable (S) and not suitable (N). The suitable category is divided into a very suitable class (S1), a suitable class (S2) and a moderately suitable class (S3). The not suitable category is grouped into a temporarily not suitable class (N1) and a permanently not suitable class (N2) (FAO 1976). Before applying a weighted linear combination equation to calculate the suitability index, these calculated ranks are standardized to measure the scale, where 0 is permanently not suitable (N2), 1 is low or temporarily not suitable (N1), 5 is moderately suitable (S3), 7 is high (S2), and 9 is very high suitability (S1). The conversion is shown in Table 6.

\subsection{Analytical Hierarchy Process (AHP)}

Analysis of land suitability requires consideration of several criteria for specific land use as explained in this study which has integrated many criteria for analysis of vineyard suitability. Although GIS has emerged as a powerful tool and method to handle spatial data in land suitability evaluation, the application of these tools alone could not overcome the issue of inconsistency in experts' opinions when trying to assign relative importance or weight to each criteria and layer and considering it in a suitability analysis (Duc2006). To solve this issue, the AHP method is used in combination with the GIS tool (Feizizadeh and Blaschke 2012; Kumar et al. 2016; Dengiz and Usul 2018; Jhariya et al. 2018; Alganci el al. 2018). AHP is designed as a system to support the optimum decision, particularly for complex circumstances with a hierarchical structure (Saaty 2008, 1990, 1980). In the AHP method, 
criteria are compared with others to get a final relative preference expressed as a numeric value.

The relative importance of criteria and sub-criteria were derived from an exploratory study that was distributed to experts and farmers in the study area to determine their opinions in assessing soil properties and their effect on vineyards. As well as the relative importance of bioclimatic indicators, which were derived from measuring the quantitative correlation between these indices and yields from vineyards in the period from 1984 to 2015. Using a pair-wise comparison matrix, criteria weights were calculated by comparing two criteria together, as shown in Tables 4-5. This pair-wise comparison allowed for an independent evaluation of the contribution of each criterion, thereby simplifying the decision-making associated with the cultivation of economic vineyards.

AHP calculates the weighting for each criterion (w1) and sub-criterion (w2), and then the sum of the components, as shown in equation (2):

$$
\sum_{\mathrm{i}=1}^{\mathrm{n}} \mathrm{Wi}=1
$$

The importance scale is suggested for these comparisons on the basis of Saaty's scaling ratios 1- 9 (Saaty, 1980).

Normally, the weights taken from a comparison matrix are consistent, and this is an important part of the method used in AHP. Therefore, one of the capacities of AHP is that it allows for inconsistent judgments and relationships while, at the same time, providing a consistency ratio $\mathrm{CR}$ equation (3). It provides information about the compatibility of preferences between a pair-wise comparison matrix (Saaty, 2008, 1990, 1980) as an indicator of the degree of consistency, using the following equation.

$$
\mathrm{CR}=\frac{\mathrm{CI}}{\mathrm{RI}}
$$

The Randomness Index (RI), depending on the order number of the matrix given by Saaty (1980), and the consistency index (CI), can be expressed as (4):

$$
\mathrm{CI}=\frac{(\lambda \max -\mathrm{n})}{\mathrm{n}-1}
$$


In which $\lambda \max$ is the largest or principal eigenvalue of the matrix, and $(n)$ is the number of the criteria used in each processing. A consistency ratio (CR) of 0.10 or less indicates a reasonable level of consistency (Saaty 1977).

For climatic suitability: $\mathrm{CI}=\frac{(7.369-7)}{7-1}=0.0496$

A Randomness Index RI = 1.32 was used, since there were seven criteria.

$$
\mathrm{CR}=\frac{0.0496}{1.32}=0.049<0.10 \text { consistent }
$$

For soil suitability: $\quad \mathrm{CI}=\frac{(6.02-6)}{6-1}=0.004$

A Randomness Index RI = 1.24 was used, since there were six criteria.

$$
\mathrm{CR}=\frac{0.004}{1.24}=0.0032<0.10 \text { consistent }
$$

Table 4 Normalized pair wise comparison matrix of the AHP method for climatic criteria

Table 5 Normalized pair wise comparison matrix of the AHP method for soil criteria

Table 6 Bioclimatic, topographic, and soil requirements for viticulture suitability, and class, degree of limitation, criteria weights and rating scale for each criterion

Fig 4. Methodological flowchart: assessing viticulture suitability

\section{Results and Discussion}

\subsection{Spatial Distribution of Climate-Viticulture Indices}

According to the spatial distribution as shown in Fig. 5, there is a high variability of these indices' values, due to the non-uniformity of the topography (from $696 \mathrm{~m}$ to $1796 \mathrm{~m}$ ) in the study area. Therefore, the diversity of these climatic regions for vineyard cultivation has led to a variety of grape cultivars and has had a direct effect on the quantity and quality of production of wine-grapes and the maturity period of grapes. 
Fig. 5 Distribution of climate-viticulture indices and heat waves and cold waves for viticulture suitability

The range in the BHI values (Fig. 6a) crossed 4 different classification limits (Table 6; Fig. 5); all values were between 2 and 4. Therefore, it was revealed that around $230.6 \mathrm{~km}^{2}$ $(44.47 \%)$ are very suitable areas for vineyards (S1). In addition, the range in the average HTC values were between $>0.2$ and $0.87 \mathrm{~mm} /{ }^{\circ} \mathrm{C}$ (Fig. 6b), but around $155.4 \mathrm{~km}^{2}$ (29.96\%) of study areas were very suitable for vineyards (S1) (Table 4; Fig. 5). However, in areas where the HTC values were below $0.5 \mathrm{~mm} /{ }^{\circ} \mathrm{C}$ (70 \% of study area), grape production is only possible if the air humidity and soil moisture is high or if irrigation is applied, so HTC values in the study area have the highest weight in the vineyard suitability evaluation.

Fig. 6 Maps of Climate-Viticulture Indices: (a) Branas Heliothermic Index BHI; (b) Hydrothermal coefficient HTC; (c) Winkler Index WI-GDD; (d) Huglin Index HI; (e)

\section{Cool Night Index CI}

The WI-GDD values between cold region (I) and hot region (V) (Fig. 6c) crossed 5 different classification limits, as shown in Table 1; Fig. 5. Furthermore, the optimum zone S1 (1671 -1940) made up around $188.44 \mathrm{~km}^{2}(20.56 \%)$ of the study area. Moreover, no portion of the study area was found to have heat summation values outside the suitable range for high quality wine and grape production. Also, HI values - somewhat similar to WI-GDD values (Fig. 6d) presented 4 different classification limits (Table 1), which ranged between temperate HI-1 and very warm HI+3, but the optimum zone S1 (1950-2250) as classified in Table 6 constituted around $18.28 \%$ of study area. Conversely, the HI values outside the suitable range N1, as calculated and shown in Table 6; Fig. 5, were around 32.5\% in western parts of study area.

In addition, the $\mathrm{CI}$ values (Fig. 6e) showed 4 different regions, as classified in Table 6; Fig. 5, where around $60.22 \%$ of study area was in the moderately suitable S3 category. The CI values play an important role during maturity (September), notably in relation to secondary metabolites (polyphenols, aromas, colour and flavour of grape juice) in grapes (Tonietto and Carbonneau, 2004), but a small area was found to have the preferred temperature at this stage, as shown in regions S1 and S2, which constituted $23.04 \%$ and 16.55 $\%$ of the study area, respectively. 
Fig. 7 Maps of heat wave and cold wave frequency during the vineyard growing season: (a) NDb15 number of days below $15^{\circ} \mathrm{C}$ during the flowering period; (b) NDh35 number of days high than $35^{\circ} \mathrm{C}$ during the ripening period

\subsection{Spatial Distribution of Soil Indicators}

Spatial analysis of soil indicators (Fig. 9) showed a wide variety in the properties of the soil in the study area, which was related to soil gneisses and soil forming factors such as topography, parent material and climatic conditions. These indicators vary greatly from the upper part to the low western slopes, and the range is especially evident in the depth, soil texture, $\mathrm{pH}$, and the percentage values of calcium carbonate $(\mathrm{CaCo} 3)$.

According to the soil indicators related to the criteria for the ecological needs of a vineyard as classified in Table 6, the results shown in Figs. 8 and 9 for the soil texture value show that clay soil is dominant, although it is not preferred. On the other hand, loamy soil, which has typical properties suitable for vineyards, was limited in area and distribution; around $48.24 \%$ of the study area was not suitable (N1), while the S1 class covered around $1.8 \%$ of study area.

\section{Fig. 8 Distribution of soil indicators for viticulture suitability}

The $\mathrm{pH}$ values of the studied soil were between 6.5 and 8 (Fig. 9c) and were divided into moderately suitable S3 (around $40 \%$ of the study area), and S2 which makes up about $54 \%$ of study area, as shown in Fig. 8 . However, no portion of the study area has pH values outside the suitable range. OM values are somewhat similar to $\mathrm{pH}$ values; in terms of relevance and distribution (Fig.9c) around $52 \%$ of the study area is in the moderately suitable class $\mathrm{S} 3$, and the rest of the area lies within $\mathrm{S} 1$ and $\mathrm{S} 2$ regions

Fig. 9 Maps of soil indicators for viticulture suitability: (a) organic matter; (b) depth;

(c) soil reactions ( $\mathbf{p H})$ of $(1: 2.5)$; (d) electrical conductivity; (e) soil's CaCO3; (f) soil texture

\subsection{Spatial Analysis of Topographic Suitability:}

The slope value has two critical effects: (1) a positive effect through facing solar radiation and (2) limited mechanization where it becomes very steep (Stanchi et al. 2013). In the study area, we defined the following 3 classes according to economical sustainability criteria for viticulture (Acharya and Yang 2015; Chen 2011), as presented in Table 6. The results showed 
(Fig. 10) about $74.24 \%$ of the study area was highly favourable (S1), where terracing may be limited, and mechanization is widely applicable. In contrast, the aspect values were almost equal for S1, S2 and S3 respectively (Fig.10). However, aspects values carried less weight in the suitability evaluation, compared to the weights given to the climatic and soil indicators (Wolf \& Boyer 2003).

\section{Fig. 10 Topographic suitability for viticulture in the study area}

\subsection{Vineyard Suitability Analysis:}

In this study, suitability evaluation for vineyards (Fig. 11) revealed that around $151.55 \mathrm{Km}^{2}$ $(28.97 \%)$ of the study area is highly favourable (S1) for vineyard growing and can be divided into 3 subclasses; A, B and C. These areas have perfect conditions in terms of climate, soil, and topography. Around $168.8 \mathrm{~km}^{2}(32.22 \%)$ of the study area were suitable (S2) but of lower value than the previous region. Besides, the moderately suitable class S3 was 122.35 $\mathrm{km}^{2}(23.4 \%)$ of the study area. As for the last region (N1), it was limited in area to around $0.01 \%$, with the rest of study area making up around $68.53 \mathrm{~km}^{2}(15.4 \%)$.

The current study provides a model proposal and novel insights for site selection for economic viticulture, built up by a GIS approach and multi-criteria evaluation MCE, considering the climatic, soil and topographic conditions; this will be helpful for farmers in developing production, upgrading production efficiency, and moving away from areas that need intensive cultivation processes. Therefore, understanding the spatial variability of these factors provides the basis for a viable characterization of each viticulture region.

\section{Conclusions}

The main environmental yariables as shown in the previous analysis play a critical role in the suitability of land for vineyard cultivation. The elevation factor has an important role in affecting climatic and soil variables.

Overall, highly suitable areas are concentrated in the higher portion (i.e. the eastern part of the study area) where favourable climate and soil are available, and did not show any relevant limitation. Conversely, the lower portion (i.e. the western part of the study area) has unfavourable climate and soil chemical and physical fertility; therefore, grape production is only possible if irrigation is applied and associated with fertilization. In addition, farmers' positive experiences in the $\mathrm{S} 1$ and $\mathrm{S} 2$ regions in the eastern portion in the study area confirm 
the results of this research, showing that good wine and grape production can be achieved in such specific environmental conditions.

Fig. 11 Final maps of vineyards suitability: (a) map of climatic suitability, (b)map of soil suitability, (c) map of topographic suitability, (d) map of agriculture area and excluded urban area

Funding: This research did not receive any specific grant from funding agencies in the public, commercial, or not-for-profit sectors. 


\section{References}

Acharya T D,Yang I T. 2015. Vineyard suitability analysis of Nepal, International Journal of Environmental Sciences, 6(1), 13-19. DOI:10.6088/ijes.6002

Alganci U, Kuru G N, Algan I Y, Sertel E. 2018. Vineyards Site Suitability Analysis by Use of Multi-Criteria Approach Applied on Geo-spatial Data, Geocarto International, https://doi.org/10.1080/10106049.2018.1493156

Alsafadi K J. 2016. Climate and its Impact on Cultivation of Apple and Grapes Crops in Alswuydaa Governorate-Syria, (Unpublished master's thesis In Arabic) Alexandria University, Alexandria, Egypt.

Amerine M A, Winkler A J.1944. Composition and Quality of Musts and Wines of California Grapes. Hilgardia, Journal of Agricultural Science, 15, 493-675.

Anderson J D, Jones G V, Tait A, Hall A, Trought M C T. 2012. Analysis of Viticulture Region Climate Structure and Suitability in New Zealand. J Int Sci Vigne Vin, 46(3),149-165 https://doi.org/10.20870/oeno-one.2012.46.3.1515

Blanco-Ward D, Monteiro A, Lopes M, Borrego C, Silveira C, Viceto C, Rocha A, Ribeiro A, Andrade J, Feliciano M, et al. 2017. Analysis of Climate Change Indices in Relation to Wine Production: A Case Study in the Douro Region (Portugal) In: J.Aurand, ed.. 40th World Congress of Vine and Wine 2017, 28-May to 2-Jun 2017, Sofia, Bulgaria: EDP Sciences, BIO Web of Conferences, (9), 1011. https://doi.org/10.1051/bioconf/20170901011

Blanco-ward D, Queijeiro J M G, Jones G V.2007. Spatial Climate Variability and Viticulture in the Miño River Valley of Spain. Vitis, 46(2), 63-70.

Branas J, Bernon G, And Levadoux L. 1946.Élements de Viticultura Générale. Imp. Déhan, Bordeaux.

Branas J. 1974. Viticulture. Imp. Déhan, Montpellier, France.

Campbell W D. 2013. Spatial Analysis of Climate and Winegrape Production in Winegrape Growing Regions of Oregon, United States of America. (Master's thesis), Available from PDX Scholar Dissertations and Theses database. (10.15760/etd.1441).

Carver S J. 1991. Integrating Multi-Criteria Evaluation with Geographical Information Systems. International Journal of Geographical Information System, 5, 321-339.

Cass A, Walker R R, Fitzpatrick R W. 1995. Vineyard Soil Degradation by Salt Accumulation and the Effect on the Performance of the Vine. Proceedings of the Ninth Australian Wine Industry Technical Conference, Adelaide pp.153-160

Chen T. 2011. Using A Geographic Information System to Define Regions of Grape-cultivar Suitability in Nebrsk. (Unpublished master's thesis), University of Nebraska-Lincoln, USA.

Day P R. 1965. Methods of Soil Analysis, Part I. Agronomy, 9, 545- 567.

Dengiz 0, Usul M. 2018. Multi-Criteria Approach with Linear Combination Technique and Analytical Hierarchy Process in Land Evaluation Studies. Eurasian Journal of Soil Science, 7 (1), $20-29$ https://doi.org/10.18393/ejss.328531

Duc T T. 2006. Using GIS and AHP Technique for Land-Use Suitability Analysis. International Symposium on Geoinformatics for Spatial Infrastructure Development in Earth and Allied Sciences, 1-6.

FAO. 1976. A Framework for Land Evaluation. Soils bulletin 32, Rome, Italy.

FAO. 1990. Guidelines for Profile Description. 3rd Edn. Rome, Italy.

Feizizadeh B, Blaschke T. 2012.Land suitability Analysis for Tabriz County, Iran: A Multi-Criteria Evaluation Approach Using GIS. Journal of Environmental Planning and Management, 1-23 iFirst article.http://dx.doi.org/10.1080/09640568.2011.646964

Fraga M, Malheiro A C, Moutinho-Pereira J, Cardoso R M, Soares P M M, Cancela J J,Pinto J G, Santos J A. 2014. Integrated Analysis of Climate, Soil, Topography and Vegetative Growth in Iberian Viticultural Regions, PLoS ONE 9(9),1-14.https://doi.org/10.1371/journal.pone.0108078

Ghosh R. 2005. Using GIS for Grape Suitability Analysis. ArcUsewww.esri.com/news/arcuser/0205/grapes.html

Gladstones J. 1992. Viticulture and Environment. Winetitles, Adelaide. 310 pp. 
Habib H. 2006. Pedological Study of Soil Toposequence in Jabal Alarab Sowaida Governorate. Journal of Damascus University for Agricultural Sciences, 22(1),181-209. (In Arabic)

Hall A, Jones G V. 2010. Spatial Analysis of Climate in Winegrape Growing Regions in Australia. Aust J Grape Wine Res, 16, 389-404.

Happ J.2014. Vineyard Site Suitability in Minnesota USA. Resource Analysis, Saint Mary's University of Minnesota University Central Services Press. Winona, (16)11pp. http://www.gis.smumn.edu .

Hennawi S.2012. Characterization and Evaluation of Some Soils from Sweaida Province Using Remote Sensing Techniques, (Unpublished Doctoral Dissertation in Arabic), Damascus University, Damascus Syria.

Hennawi S, Habib H. 2012. The Impact of Spatial Variation on Some Morphological and Chemical Properties of Some Soils from the Western Slope of Jabal Al Arab. Journal of Damascus University for Agricultural Sciences, 28(2), 435-454. (In Arabic)

Hennawi S, Habib H. 2013. Some Pedological and Fertility Characteristics of Some Soils of Jabal Al Arab and Hauran Plain. Journal of Damascus University for Agricultural Sciences, 29(1), 239-252. (In Arabic)

Huglin P. 1978. Nouveau Mode d'Évaluation des Possibilités Héliothermiques d'un Milie Viticole. C. R. Acad. Agr. France, 1117-1126.

Hunter J J,Bonnardot V. 2011. Suitability of Some Climatic Parameters for Grapevine Cultivation in South Africa, with Focus on Key Physiological Processes. S Afr J Enol Vitic 32(1), 137-154.

Jackson R S. 2000. Wine science. Principles, Practice, Perception. Academic, San Diego, USA.

Jacob H E. 1950. Grape growing in California. California Agricultural Extension Service, College of Agriculture, University of California. Berkeley.

Jhariya D C, Kumar T, Panday H k. 2018. Watershed prioritization based on soil and water hazard model using remote sensing, Geographic Information Systems and multi-criteria Decision Analysis Approach, Geocarto International, https://doi.org/10.1080/10106049.2018.1510039

Jones G V. 2015. Climate, Grapes, and Wine; Terroir and Importance of Climate to Wine-grape Production. GuildSomm Organization. Retrieved from

www.guildsomm.com/public content/feature/articles/b/gregory_jones/posts/climte-grapes-and-wine

Jones G V, Andrew A D, Duff A, Hall A, Myers J W. 2010. Spatial Analysis of Climate in Winegrape Growing Region in the Western United States. Am. J. Enol. Vitic. 61,313-326.

Jones G V, Duff A A, Hall A. 2009. Updated Analysis of Climate-Viticulture Structure and Suitability in the Western United States. In The 16th International GiESCO Symposium-Davis,12-Jul to15-Jul 2009, California,USA: Viticulture \&Enology, UC Davis.

Jones G V, Snead N, Nelson P.2004. Geology and Wine 8. Modelling Viticultural Landscapes: A GIS Analysis of the Terroir Potential in the Umpqua Valley of Oregon. Geoscience Canada, 31 (4), 167-178.

Jones G V, WhiteM A,Cooper O R, Storchmann K. 2005. Climate Change Global Wine Quality. Climatic change, 73(3), 319-343.

Kiwan S. 2014. Some Pedological and Fertility Characteristics of Some Soils from the South Area of Swaida. (Unpublished master's thesis In Arabic), Damascus University, Damascus Syria

Kliewer W M. 1973. Berry composition of Vitis vinifera Cultivars as Influenced by photo-temperatures and Nycto-temperatures During maturation. J Am Soc Hortic Sci, 98, 153-159.

Kliewer W M, Torres R E. 1972. Effect of controlled day and night temperatures on grape coloration. Am. J. Enol.Vitic. (2),71-77.

Kose B. 2014. Phenology and Ripening of VitisVinifera L. And Vitis Labrusca L. Varieties in The Maritime Climate of Samsun in Turkey's Black Sea Region. S Afr J Enol Vitic 35(1), 90-102.

Koufos G C, Mavromatis T, Koundouras S, Jones G V. 2017. Response of Viticulture-Related Climatic Indices and Zoning to Historical and Future Climate Conditions in Greece. International Journal of Climatology, 38(4), 2097-2111.https://doi.org/10.1002/joc.5320

Kumar S, Srivastava P K, Snehmani. 2016. GIS- based MCDA - AHP Modelling for Avalanche Susceptibility Mapping of Nubra Valley Region, Endian Himalaya. Geocarto International, http://dx.doi.org/10.1080/10106049.2016.1206626 
Kumara K J C, Sendanayake S. 2016. GIS Multi-Criteria Analysis to Explore Potential Wine-Grape Growing Sites in the Tropics. Imperial Journal of Interdisciplinary Research (IJIR), 2(8), 537-542.

Kurtural S K, Dami I, Taylor B H. 2006. Utilizing GIS Technologies in Selection of Suitable Vineyard Sites. International Journal of Fruit Science, 6(3), 87-107. http://dx.doi.org/10.1300/I492v06n03 07

Kurtural S K, Dami I, Wilson P E. 2008. Vineyard Site Selection in Kentucky Based on Climate and Soil Properties. University of Kentucky Cooperative Extension Service. HortFact-31-02

Labay A.2017. Obtaining and Understanding Soil and Water Tests. Texas Winegrower, 1(2)4-5.

Lanyon, D., Cass, A., \& Hansen, D. (2004). The Effect of Soil Properties on Vine Performance. CSIRO Land and Water Technical Report: Australia, No. 34/04, p54.

Lebrun S C R.2016. Wine Typicality and Vine Responses to Terroir Constraints, Master Thesis. AgroParisTech, Paris France. 34p

Lorenzo M N, Taboada J J, Lorenzo JF, Ramos A M. 2013. Influence of Climate on Grape Production and Wine Quality in the Ri'asBaixas, North-Western Spain. Regional Environmental Change, 13(4), 887-896. https://doi.org/10.1007/s10113-012-0387-1

MacCracken R F, Houser P R. 2016. Spatial Analysis of Climate-Viticulture Indices for the Eastern United States. International Journal of Applied Geospatial Research, 7(4), 23-37. https://doi.org/10.4018/IJAGR.2016100102

Malczewski J. 1999. GIS and Multi-Criteria Decision analysis. Wiley \& Sons Inc. New York, USA.

Malczewski J. 2000. On the Use of Weighted Linear Combination Method in GIS: Common and Best Practice Approaches. Transactions in GIS, 4(1), 5-22.

Melan A 0. 1982. Methods of Soil Analysis. Part II (2nd ed.), Madison, American Society of Agronomy. P. 1159.

Mesterházy I, Mészáros R, Pongrácz R. 2014. The Effects of Climate Change on Grape Production in Hungary. Quarterly Journal of the Hungarian Meteorological Service, 118(3), 193-206.

Mills-Novoa M, Pszczólkowski P, Meza F.2016.The Impact of Climate Change on the Viticultural Suitability of Maipo Valley Chile. The Professional Geographer 68(4),561. https://doi.org/10.1080/00330124.2015.1124788

Mustafa A A, Sing M, Sahoo R N, Ahmed N, Khanna M, Sarang A, Mishra A K. 2011. Land Suitability Analysis for Different Crops: A Multi Criteria Decision Making Approach using Remote Sensing and GIS. Researcher, 12(3), 61-84.

Nelson DW, Sommers L E. 1982. Methods of Soil Analysis. Part II (2nd Edition), Madison, pp. 1159.

Rhoades J D. 1982. Cation Exchange Capacity. In: Methods of Soil Analysis, Part 2; Chemical and Microbiological Properties, eds. A.L. Page, R.H. Miller, and D.R. Keeney, Madison, Wisconsin: 2nd ed. American Society of Agronomy, p: 149-158.

Saaty T L. 1977. A Scaling Method for Priorities in Hierarchical Structure. Journal of mathematical psychology, 15 (3), 34-39.

Saaty T L. 1980. The analytic hierarchy process: planning, priority setting, resources allocation. McGrawHill, New York.

Saaty T L. 1990 How to make decision: the analytic hierarchy process. Eur J Oper Res, 48, 9-26.

Saaty T L. 2008. Decision Making with the Analytic Hierarchy Process. Int. J. Services Sciences, 1(1), 8393.

Santos J A, Costa R, Fraga H. 2018. New Insights into Thermal Growing Conditions of Portuguese Grapevine Varieties under Changing Climates. Theoretical and Applied Climatology, 1-12. (https://doi.org/10.1007/s00704-018-2443-3).

Stanchi S, Godone D, Belmonte S, Freppaz M, Galliani C, Zanini E. 2013. Land Suitability Map for Mountain Viticulture: a Case Study in Aosta Valley (NW Italy). Journal of Maps, 9(3), 367-372. https://doi.org/10.1080/17445647.2013.785986

Syrian Ministry of Agriculture and Agrarian Reform (SMOAAR), Statistical group 2015.

http://moaar.gov.sy 
Sys I C, Van Ranst B, Debaveye J. 1991. Land Evaluation. Part I. Principles in land Evaluation and Crop Production Calculations. international training Center for post graduate soil scientists, University Ghent.

Tonietto J, Carbonneau A. 2004. A Multi-Criteria Climatic Classification System for Grape-Growing Regions Worldwide. Agricultural and Forest Meteorology, (124), 81-97.

Ubalde J M, Sort X, Zayas A, Poch R M. 2010. Effects of soil and Climatic Conditions on Grapes Ripening and Wine Quality of Cabernet Sauvignon, Journal of Wine Research, 21(1), 1-17. http://dx.doi.org/10.1080/09571264.12010.495851

United States Geological Survey (USGS), NASA's Shuttle Radar Topography Mission (SRTM). (https://earthexplorer.usgs.gov)

Vasconcelos M C, Greven M, Winefield C S, Trought M C T, Raw V. 2009. The Flowering Process of Vitis vinifera: A Review. Am. J. Enol. Vitic. 60(4),411-434.

Virto I, Antón R, Apesteguía M, Plante A. 2018. Role of carbonates in the physical stabilization of soil organic matter in agricultural Mediterranean soils. In Soil Management and Climate Change (pp. 121-136). https://doi.org/10.1016/B978-0-12-812128-3.00009-4

Watkins R L. 1997. Vineyard Site Suitability in Eastern California. GeoJournal, 43 (3), 229-239

White R E. 2003 Soils for Fine Wines. New York, USA: Oxford University Press

White R E. 2009 Understanding Vineyards Soils. New York, USA: Oxford University Press

Winkler A J, Cook J A,Kliewer W M, Lider L A. 1974. General Viticulture. 4th ed. University of California Press, Berkeley.

Wolf T K, Boyer J D. 2003. Vineyard Site Selection. Virginia Tech, Blacksburg (Pub No 463-020).

\section{Legend of tables}

Table 1 Climate-Viticulture Indices (bioclimatic), definitions and classified limits

Table 2 Estimation of the frequency of heat waves and cold waves during ripening and flowering stages, based on daily temperature data from 1984 - 2014 at Alswuydaa and Ain Al-Arab stations.

Table 3 Weighting factor classification.

Table 4 Normalized pair wise comparison matrix of the AHP method for climatic criteria

Table 5 Normalized pair wise comparison matrix of the AHP method for soil criteria

Table 6 Bioclimatic, topographic, and soil requirements for viticulture suitability, and class, degree of limitation, criteria weights and rating scale for each criterion 
Table 1 Climate-Viticulture Indices (bioclimatic), definitions and classified limits.

\begin{tabular}{|c|c|c|c|c|}
\hline $\begin{array}{l}\text { Climate- } \\
\text { Viticulture } \\
\text { Indices }\end{array}$ & Definition & \multicolumn{2}{|c|}{$\begin{array}{c}\text { Class of viticultural climateand class } \\
\text { interval }\end{array}$} & Sources \\
\hline $\begin{array}{l}\text { (1) Branas } \\
\text { Heliothermic } \\
\text { Index (BHI) }\end{array}$ & $\begin{array}{l}\quad\left(\mathrm{T}_{\text {avg }}-10^{\circ} \mathrm{C}\right) * \sum \mathrm{I}_{\mathrm{e}}{ }^{*} 10^{-6} \sum \\
\mathrm{T}_{\text {avg }}: \text { Average temperature calculated for } 1 \text { April } \\
\text { to } 30 \mathrm{Sept} ; \\
\mathrm{I}_{\mathrm{e}}: \text { annual effective insolation }\end{array}$ & Not suitable below 2.6 & & $\begin{array}{l}\text { (Branas, } \\
1974)\end{array}$ \\
\hline $\begin{array}{l}(2) \\
\text { Hydrother- } \\
\text { mal } \\
\text { Coefficient } \\
\text { (HTC) }\end{array}$ & $\begin{array}{l}\qquad \mathrm{HTC}=10 \mathrm{P} / \mathrm{T}_{0} \\
\mathrm{P} \text { : the precipitation during the growing season } \\
\text { in } \mathrm{mm} \\
\mathrm{T}_{0} \text { : the sum of effective degree days above } 10 \\
{ }^{\circ} \mathrm{C}\end{array}$ & $\begin{array}{l}\text { Not suitable below } 0.5 \\
\text { Max } 1.5-2.5 \\
\text { optimal value }=1\end{array}$ & & $\begin{array}{l}\text { (Branas, } \\
1946)\end{array}$ \\
\hline $\begin{array}{l}\text { (3) Winkler } \\
\text { Index (WI- } \\
\text { GDD) }\end{array}$ & $\sum_{1 \text { April }}^{31 \text { October }}\left(\frac{\text { Tmax }+ \text { Tmin }}{2}\right)-10$ & $\begin{array}{l}\text { To cold } \\
\text { Region I cold } \\
\text { Region II moderately cold } \\
\text { Region III warm } \\
\text { Region IV moderately war } \\
\text { Region V hot } \\
\text { To hot }\end{array}$ & $\begin{array}{c}<850 \\
850 \text { to } 1390 \\
1391 \text { to } 1670 \\
1671 \text { to } 1940 \\
1941 \text { to } 2220 \\
2221 \text { to } 2700 \\
>2700\end{array}$ & $\begin{array}{l}\text { merine anc } \\
\text { Winkler } \\
1944)\end{array}$ \\
\hline $\begin{array}{l}\text { (4) Huglin } \\
\text { Index (HI) }\end{array}$ & $\begin{array}{l}\sum_{1 \text { April }}^{30 \text { september }}\left(\frac{(\text { Tmean }-10)+(\text { Tmax }}{2}\right. \\
\text { d: The coefficient length of day }(d) \text { by } \\
\text { latitude for the HI index: } \leq 40^{\circ}=1\end{array}$ & $\begin{array}{l}\text { Very cool (HI-3) } \\
\text { Cool (HI-2) } \\
\text { Temperate (HI-1) } \\
\text { Temperate warm (HI+1) } \\
\text { Warm (HI+2) } \\
\text { Very warm (HI+3) }\end{array}$ & $\begin{array}{l}<1500 \\
1500 \text { to } 1800 \\
1800 \text { to } 2100 \\
2100 \text { to } 2400 \\
2400 \text { to } 2700 \\
>2700\end{array}$ & (Huglin 1978) \\
\hline $\begin{array}{l}\text { (5) Cool Night } \\
\text { Index (CI) }\end{array}$ & $\begin{array}{l}\text { In the Northern Hemisphere: } \mathrm{CI}= \\
\text { minimum air temperature in the } \\
\text { month of September (mean of } \\
\text { minima), in }{ }^{\circ} \mathrm{C}\end{array}$ & $\begin{array}{l}\text { Very cool nights }(\mathrm{CI}+2) \\
\text { Cool nights }(\mathrm{CI}+1) \\
\text { Temperate night }(\mathrm{CI}-1) \\
\text { Warm nights }(\mathrm{CI}-2)\end{array}$ & $\begin{array}{l}\leq 12 \\
>12 \leq 14 \\
>14 \leq 18 \\
>18\end{array}$ & $\begin{array}{l}\text { (Tonietto and } \\
\text { Carbonneau } \\
\text { 2004) }\end{array}$ \\
\hline
\end{tabular}


Table 2 Estimation of the frequency of heat waves and cold waves during ripening and flowering stages, based on daily temperature data from 1984 - 2014 at Alswuydaa and Ain Al-Arab stations.

\begin{tabular}{|c|c|c|c|c|c|c|}
\hline \multirow[b]{2}{*}{ Equation } & \multicolumn{6}{|c|}{ Parameter Estimates } \\
\hline & R Square & Constant & b1 & $\mathrm{b} 2$ & b3 & Sig. \\
\hline $\begin{array}{l}\text { Number of days below } 15^{\circ} \mathrm{C}(\mathrm{NDb} 15) \\
\text { during flowering period* }\end{array}$ & 0.799 & 136.106 & $-12.570-$ & 0.289 & 0.0001 & $<0.001$ \\
\hline $\begin{array}{l}\text { Number of days higher than } 35^{\circ} \mathrm{C} \\
\text { (NDh35) during the ripening period } * *\end{array}$ & 0.751 & 76.042 & 0.0001 & $-0.324-$ & .0080 & $<0.001$ \\
\hline
\end{tabular}

Table3 Weighting factor classification

\begin{tabular}{cll}
\hline Depth & Section number & Weighting Factor \\
\hline $125-150$ & 6 & $2-1.5-1-0.75-0.5-0.25$ \\
$100-125$ & 5 & $1.75-1.5-1-0.5-0.25$ \\
$75-100$ & 4 & $1.75-1.25-0.75-0.25$ \\
$50-75$ & 3 & $1.5-1-0.75$ \\
$25-50$ & 2 & $1.25-0.75$ \\
$0-25$ & 1 & 1 \\
\hline
\end{tabular}

Table 4 Normalized pair wise comparison matrix of the AHP method for climatic criteria

\begin{tabular}{c|ccccccc|cc}
\hline criteria & BHI & Wink & HI & CI & HTC & NDh35 & NDb15 & wi & $\begin{array}{c}\text { Consistancy } \\
\text { Measure }\end{array}$ \\
\hline BHI & 0.141 & 0.190 & 0.120 & 0.144 & 0.121 & 0.205 & 0.245 & 0.167 & 7.666 \\
WI-GDD & 0.035 & 0.048 & 0.080 & 0.029 & 0.061 & 0.103 & 0.031 & 0.055 & 7.100 \\
HI & 0.047 & 0.024 & 0.040 & 0.024 & 0.061 & 0.026 & 0.020 & 0.034 & 7.296 \\
CI & 0.141 & 0.238 & 0.240 & 0.144 & 0.121 & 0.205 & 0.184 & 0.182 & 7.478 \\
HTC & 0.565 & 0.381 & 0.320 & 0.576 & 0.486 & 0.308 & 0.429 & 0.438 & 7.697 \\
NDh35 & 0.035 & 0.024 & 0.080 & 0.036 & 0.081 & 0.051 & 0.031 & 0.048 & 7.098 \\
NDb15 & 0.035 & 0.095 & 0.120 & 0.048 & 0.069 & 0.103 & 0.061 & 0.076 & 7.247 \\
\hline
\end{tabular}


Table 5 Normalized pair wise comparison matrix of the AHP method for soil criteria

\begin{tabular}{c|cccccc|cc}
\hline criteria & soil texture & soil depth & EC & pH & CaCo3 & OM & wi & $\begin{array}{c}\text { Consistancy } \\
\text { Measure }\end{array}$ \\
\hline $\begin{array}{c}\text { soil } \\
\text { texture } \\
\text { soil }\end{array}$ & 0.1587 & 0.1595 & 0.1606 & 0.1606 & 0.1587 & 0.1565 & 0.1591 & 6.0210 \\
depth & 0.1397 & 0.1403 & 0.1400 & 0.1399 & 0.1398 & 0.1419 & 0.1403 & 6.0212 \\
EC & 0.1365 & 0.1375 & 0.1363 & 0.1365 & 0.1374 & 0.1358 & 0.1367 & 6.0209 \\
$\mathbf{p H}$ & 0.1143 & 0.1137 & 0.1132 & 0.1137 & 0.1128 & 0.1217 & 0.1149 & 6.0218 \\
$\mathbf{C a C o 3}$ & 0.2444 & 0.2441 & 0.2427 & 0.2445 & 0.2453 & 0.2413 & 0.2437 & 6.0209 \\
$\mathbf{O M}$ & 0.2063 & 0.2049 & 0.2072 & 0.2047 & 0.2060 & 0.2028 & 0.2053 & 6.0209 \\
\hline
\end{tabular}




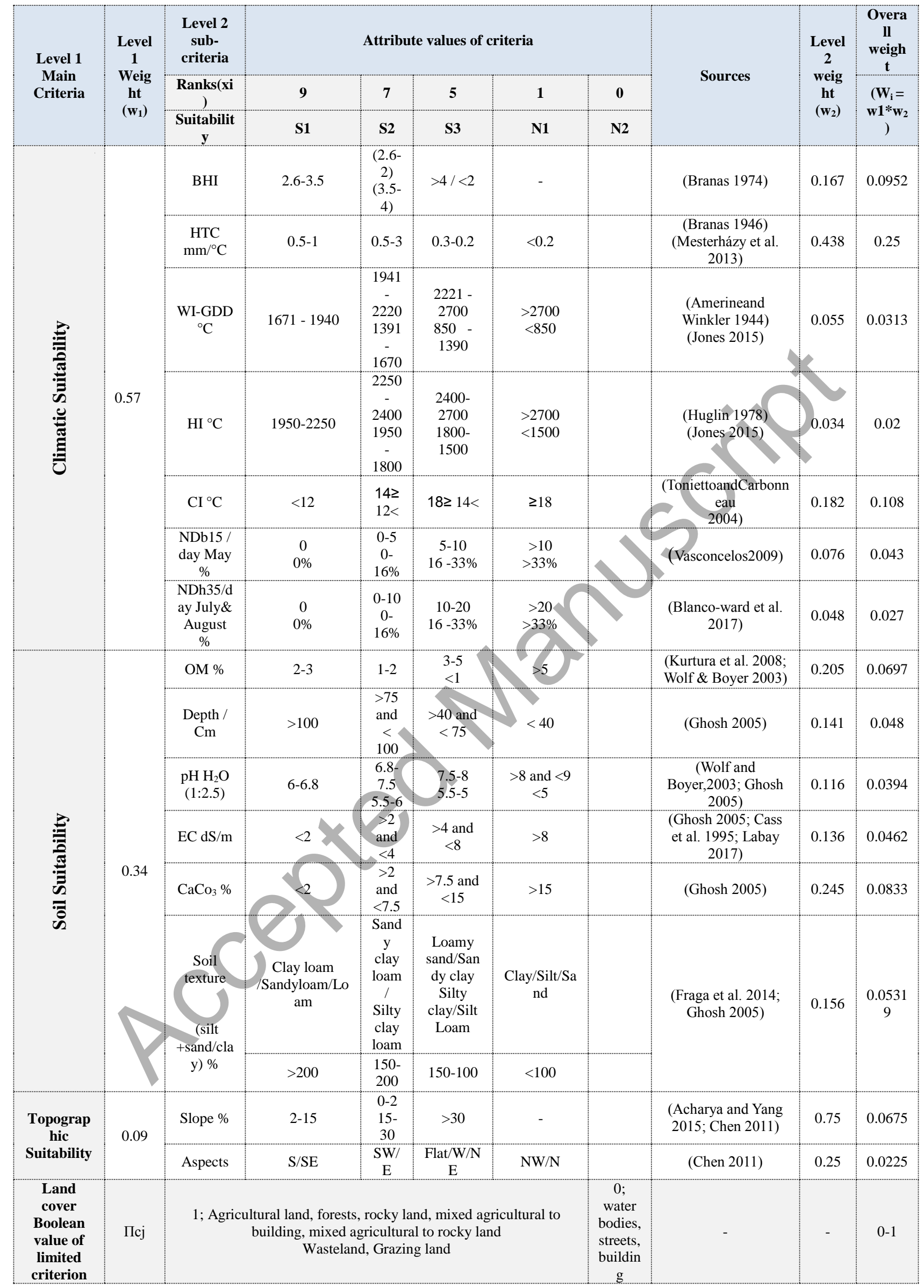


Table 6 Bioclimatic, topographic, and soil requirements for viticulture suitability, and class, degree of limitation, criteria weights and rating scale for each criterion. 


\section{Figure captions:}

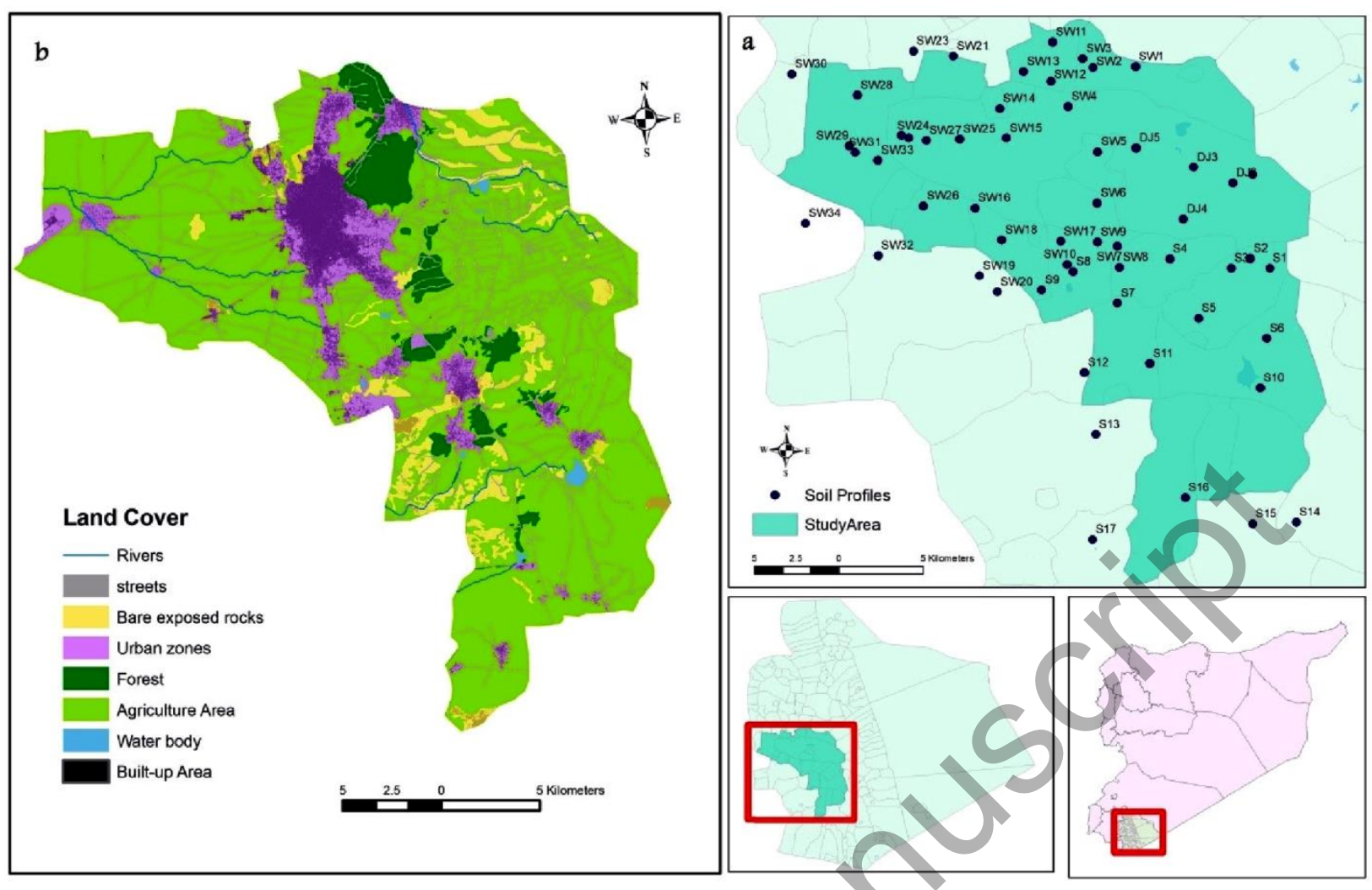

Fig. 1 (a) Location of the study area from the Al-Sweidaa governorate and sites of soil profiles, (b) Land cover map. 


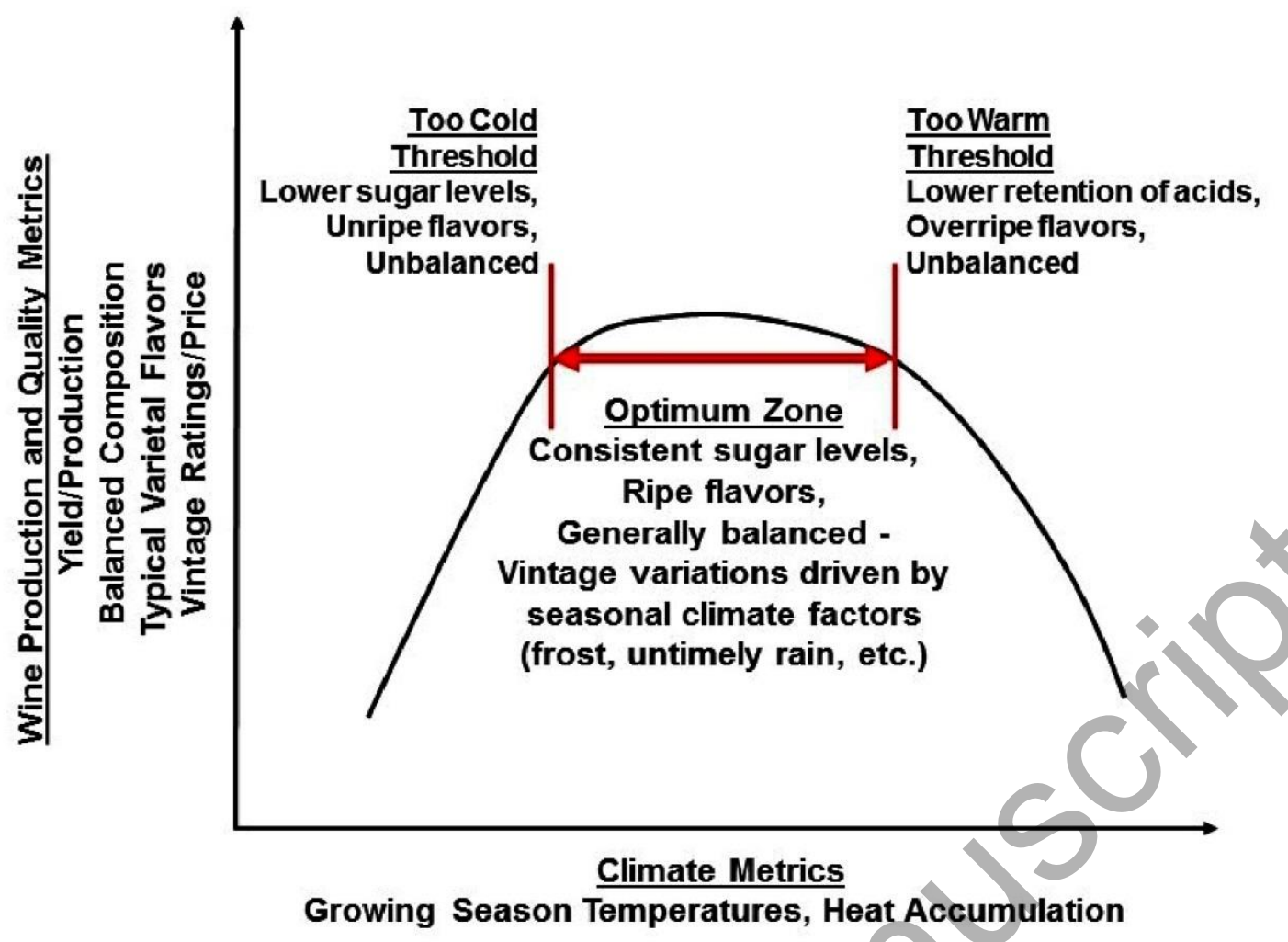

Fig. 2 Relationship and thresholds between climate and wine production and quality metrics (Jones 2015). 

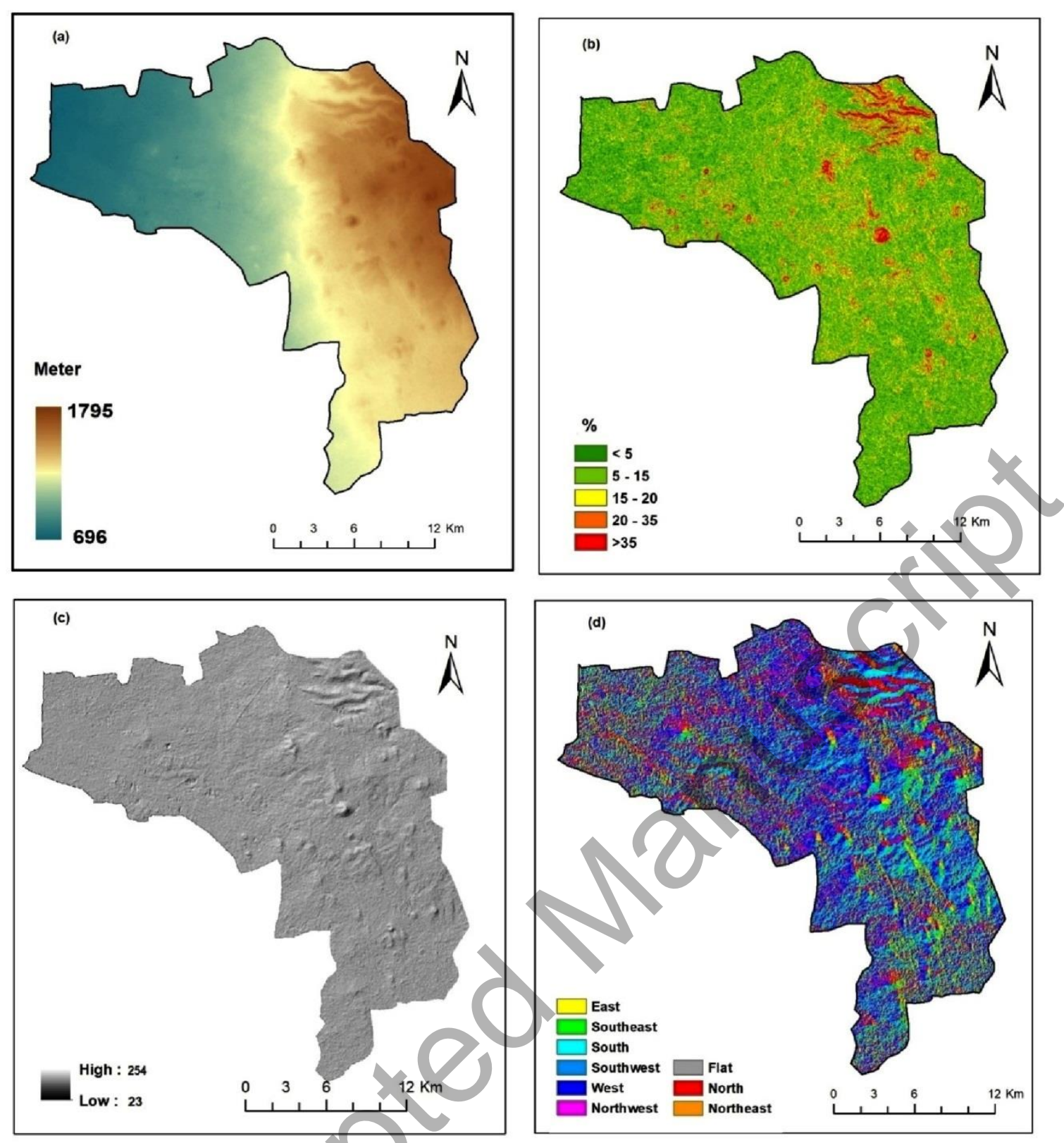

Fig. 3 Topographic characteristics (a) elevation (b) slope-percentage

(C) hill-shade, (d) aspect. 


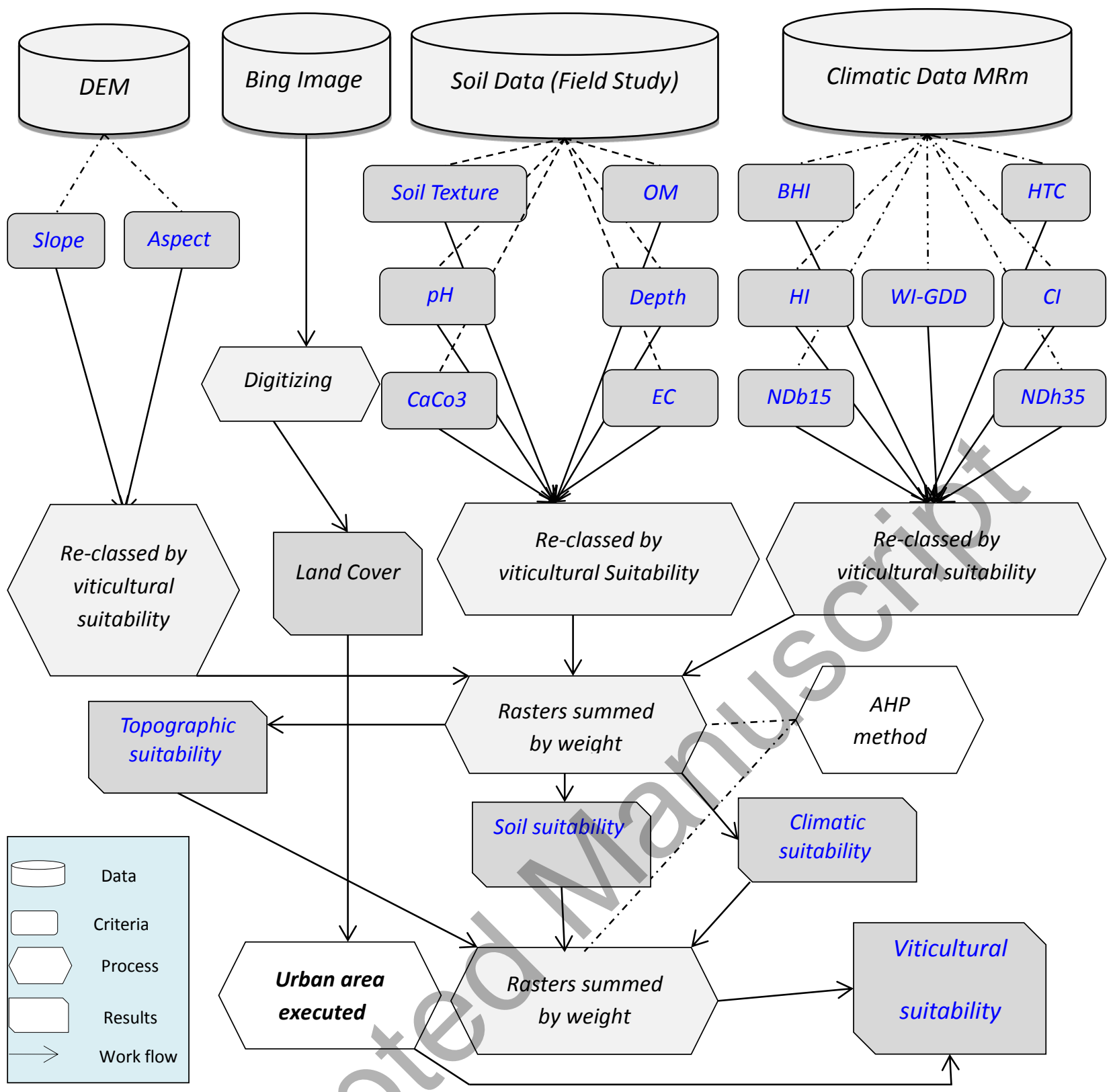

Fig 4. Methodological flowchart: assessing viticulture suitability. 


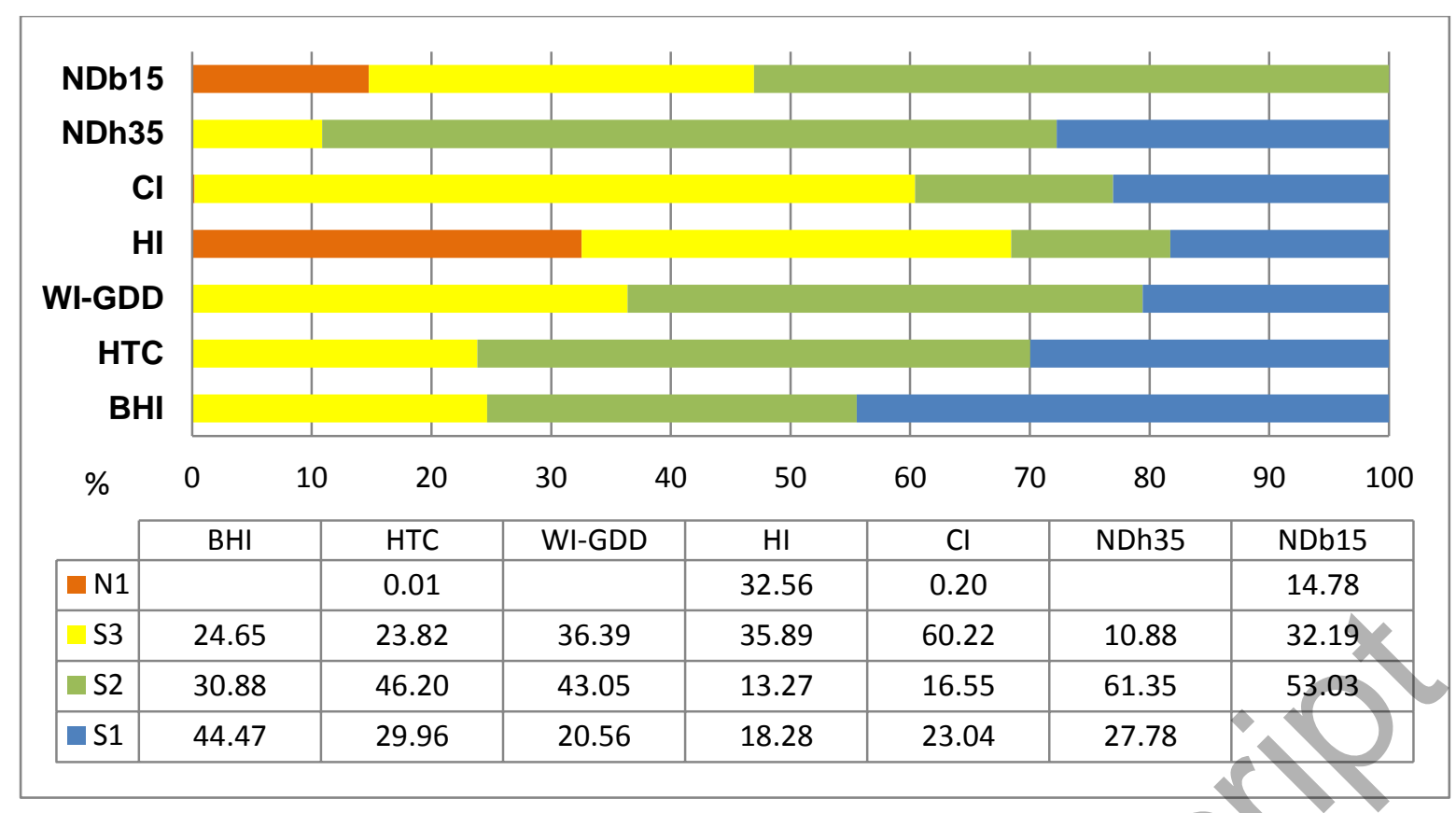

Fig. 5 Distribution of climate-viticulture indices and heat waves and cold waves for viticulture suitability. 


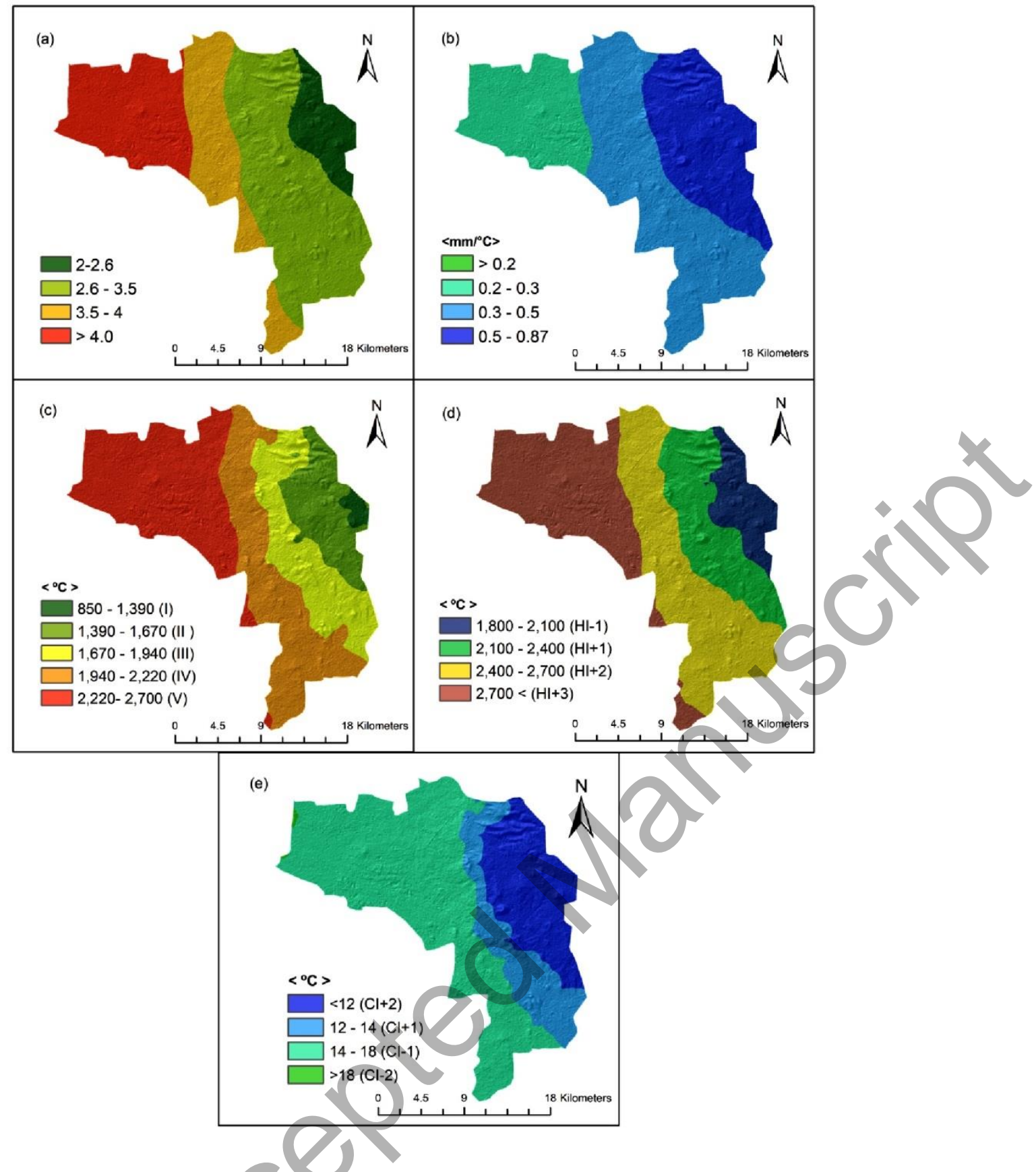

Fig. 6 Maps of Climate-Viticulture Indices: (a) Branas Heliothermic Index BHI; (b)Hydrothermal coefficient HTC; (c) Winkler Index WI-GDD; (d) Huglin Index HI; (e) Cool Night Index CI. 


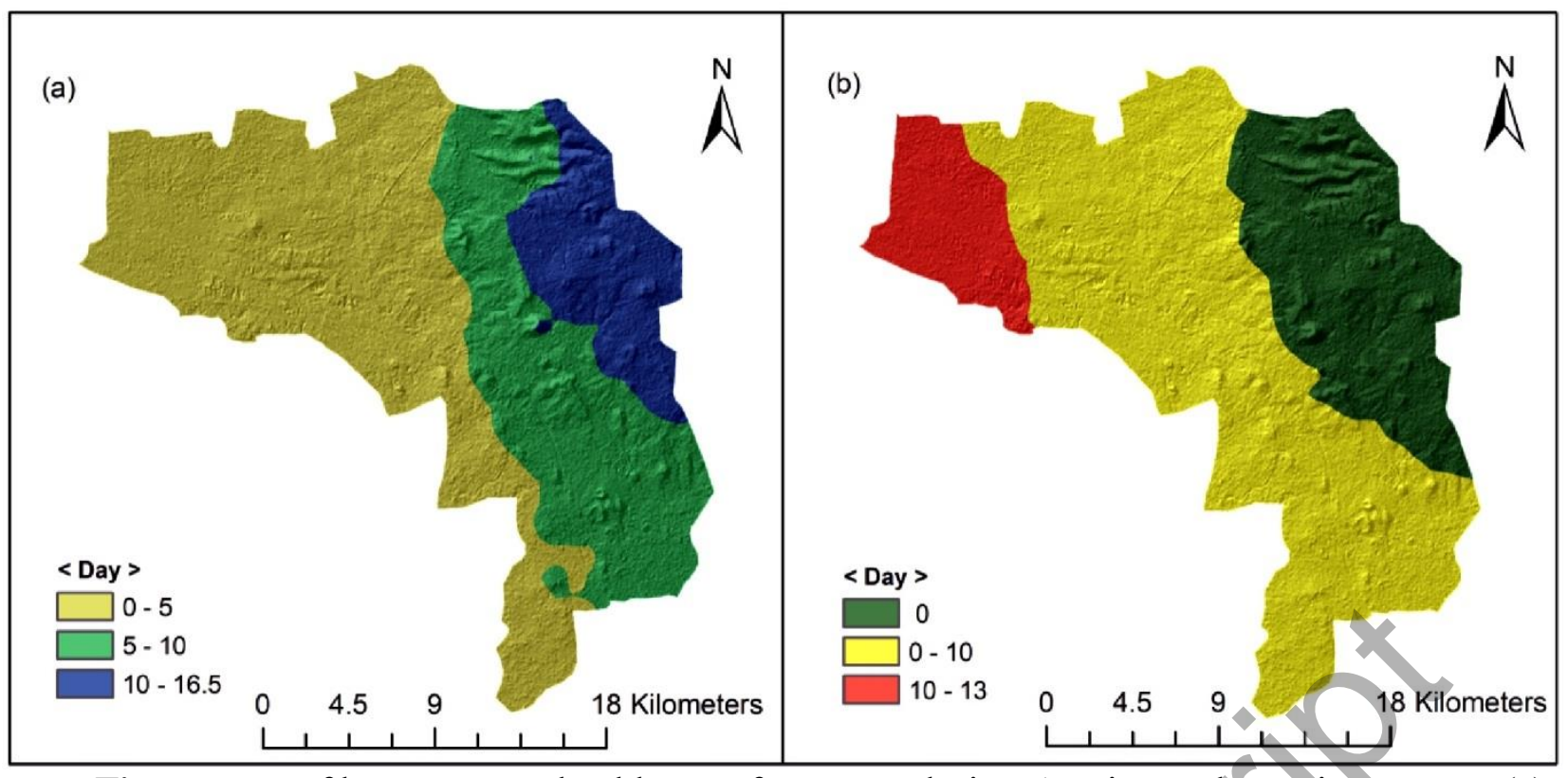

Fig. 7 Maps of heat wave and cold wave frequency during the vineyard growing season: (a) $\mathrm{NDb} 15$ number of days below $15^{\circ} \mathrm{C}$ during the flowering period; (b) NDh35 number of days high than $35^{\circ} \mathrm{C}$ during the ripening period.

\begin{tabular}{|r|r|r|r|r|r|r|}
\hline $\begin{array}{r}\text { CaCo3 } \\
\text { Depth } \\
\text { EC }\end{array}$ \\
$\begin{array}{r}\text { OMM } \\
\text { pH }\end{array}$ \\
Soil Texture
\end{tabular}

Fig. 8 Distribution of soil indicators for viticulture suitability. 


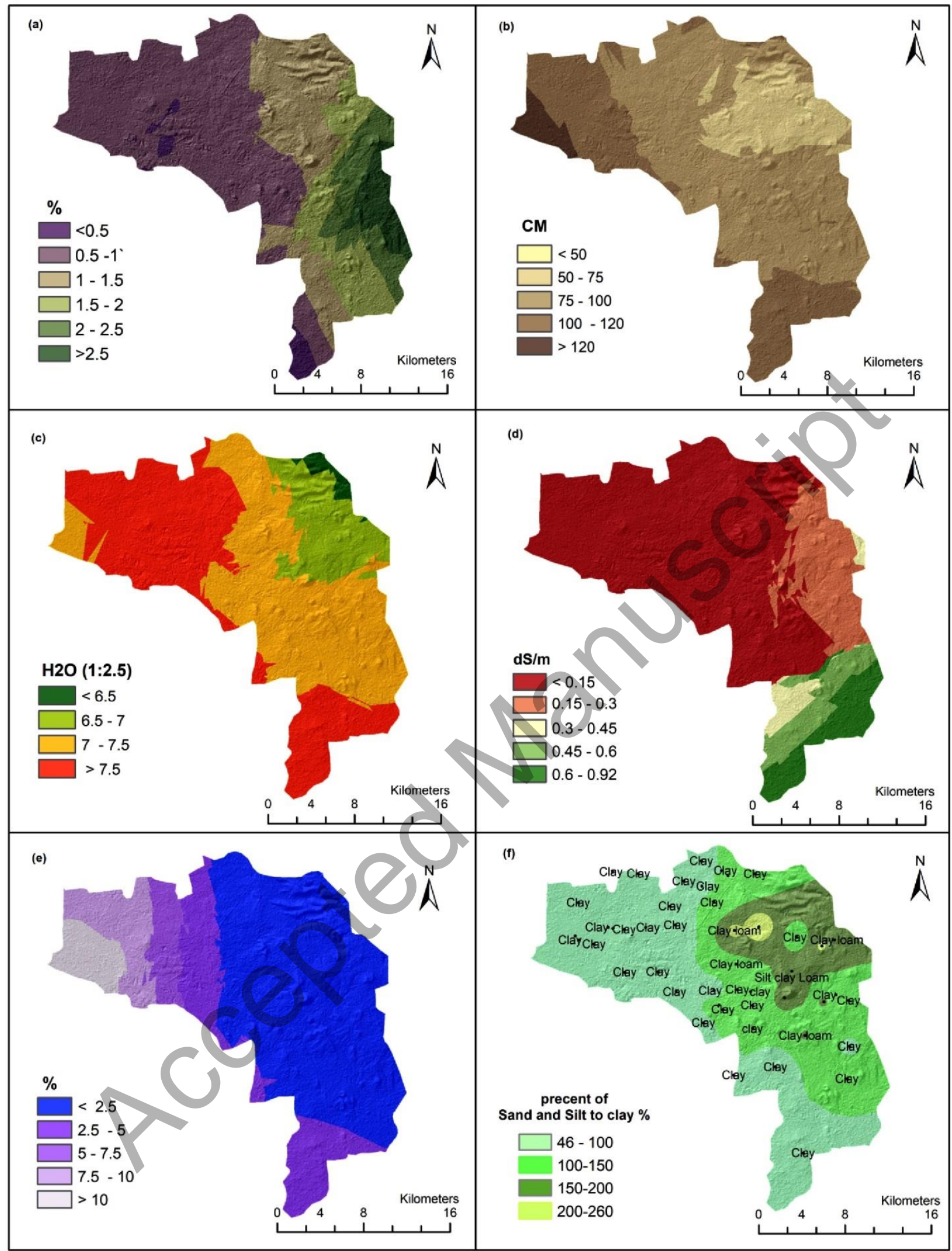

Fig. 9 Maps of soil indicators for viticulture suitability: (a) organic matter; (b) depth; (c) soil reactions $(\mathrm{pH})$ of (1:2.5); (d) electrical conductivity; (e) soil's CaCO3; (f) soil texture. 


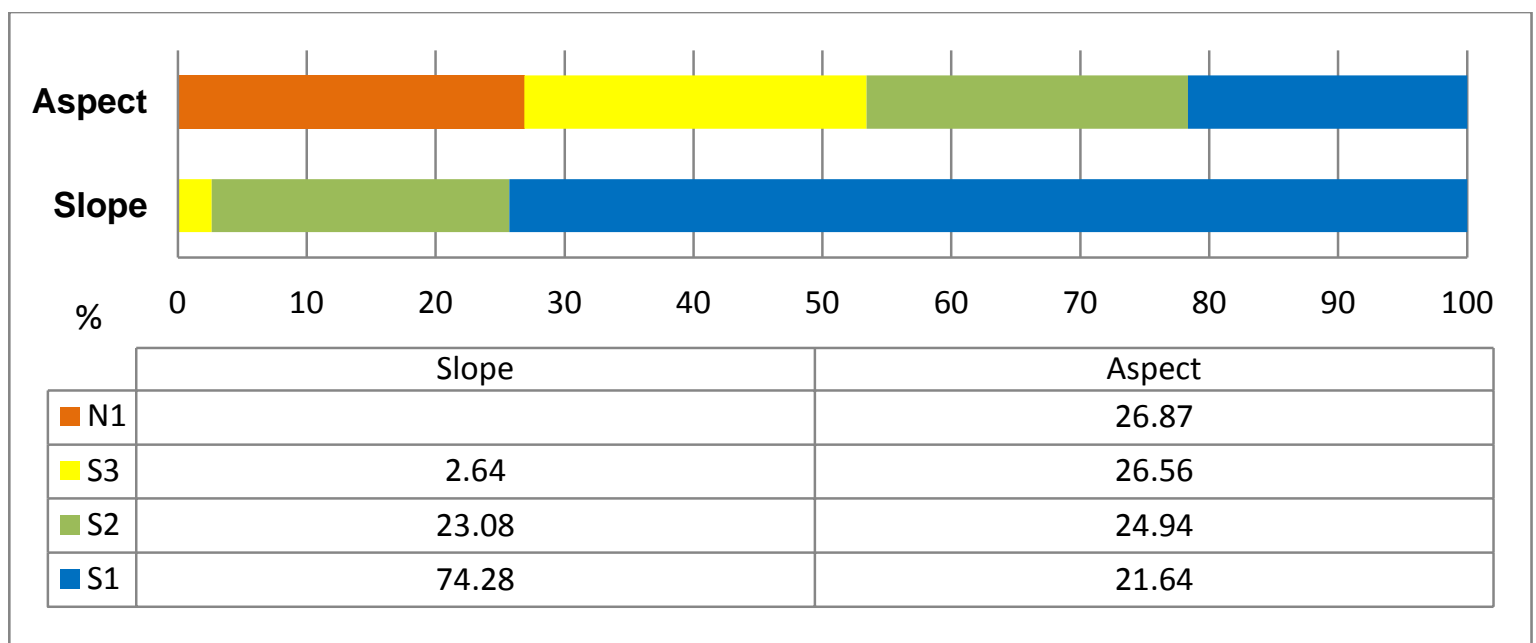

Fig. 10 Topographic suitability for viticulture in the study area. 


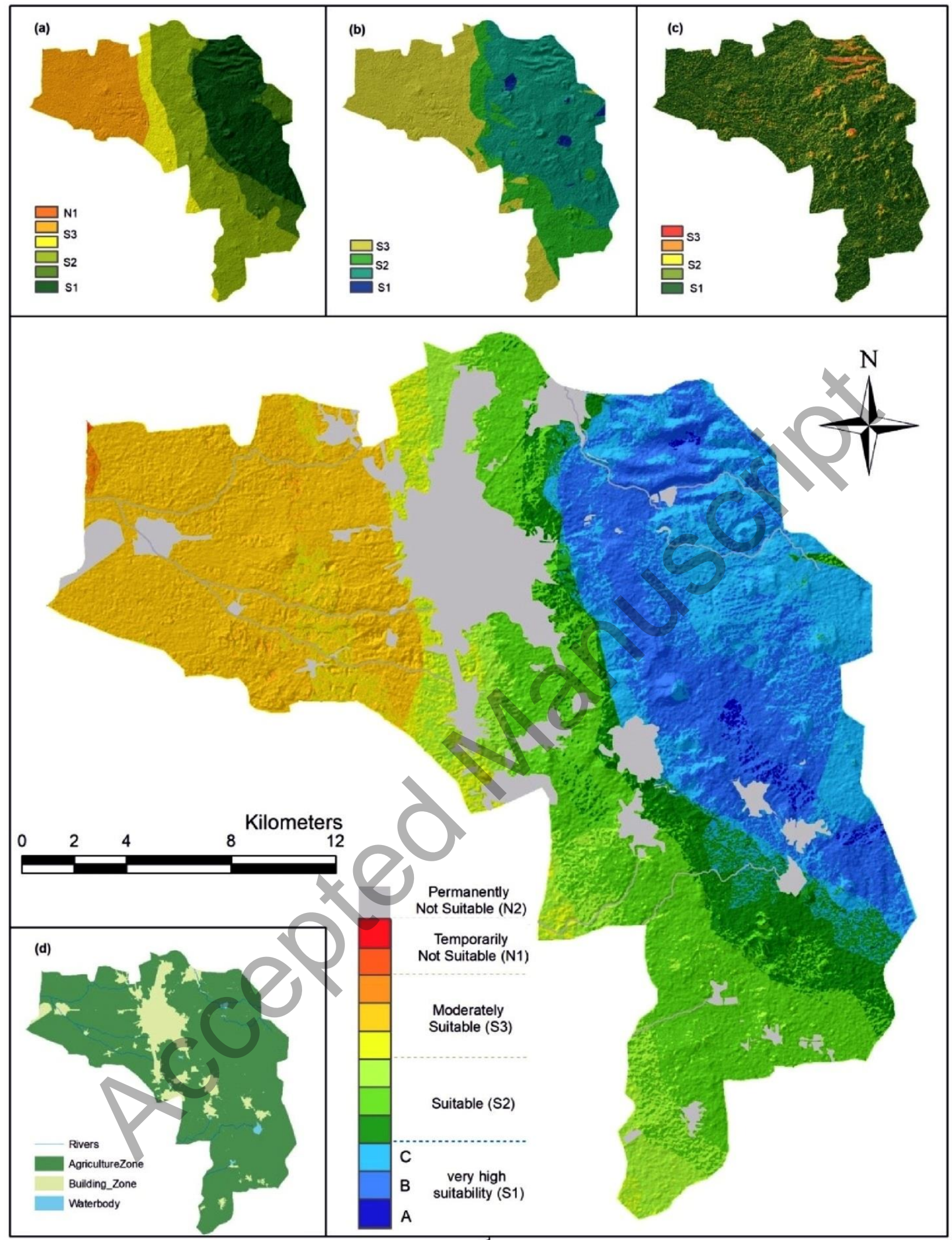

Fig. 11 Final maps of vineyards suitability: (a) map of climatic suitability, (b)map of soil suitability, (c) map of topographic suitability, (d) map of agriculture area and excluded urban area 